\title{
ÉTICA NA POLÍTICA E NA EMPRESA: 12 ANOS DE REFLEXÃO
}

\author{
Por José Henrique de Faria
}

Professor Titular do Departamento de Administração Geral e Aplicada da UFPR.

E-mail: jhfaria@ufpr.br

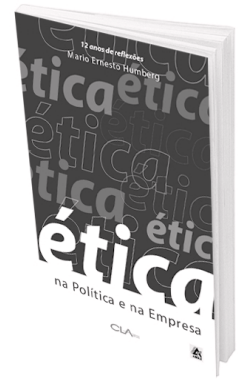

ÉTICA NA POLÍTICA E NA EMPRESA: 12 ANOS DE REFLEXÃO

De Mário Ernesto Humberg

São Paulo : CLA, 2002. 122 p.

O livro de Humberg reúne uma seleção de artigos sobre o tema da ética originalmente publicados em jornais e revistas. Não há de se ponderar sobre a escolha e a oportunidade do tema, tão atual hoje quanto para os pré-socráticos. Ética e moral são processos interligados e por vezes complementares, o que nos coloca diante de uma tarefa reflexiva nem sempre fácil.

A questão da relação entre ética e moral põe-se de forma a tentar compreender as razões pelas quais uma pessoa ou um grupo venha a agir de determinada maneira ou de outra dadas as alternativas possíveis. Assim, julgar as ações ou omissões, aprovando as consideradas boas ou censurando as consideradas más, está relacionado ao objeto sobre o qual incide a judicação moral. As sanções morais, dessa maneira, funcionam como finalidade do próprio julgamento, sendo sociais - quando se referem ao outro - e da consciência, - quando se referem a si. É um fato normal e inevitável que as pessoas julguem o modo de agir e de ser de outras pessoas, o mesmo ocorrendo com e no interior dos grupos e das organizações. Quando o que anima os julgamentos são códigos fundados em princípios éticos coletivamente construídos, pode-se mesmo falar em moral da cooperação ou em moralidade social. Mas quando o julgamento funda-se em dogmas e crenças que pertencem à natureza particular de pessoas, grupos, organizações, seitas ou corporações ou quando se baseia em um discursocobertura, que atende conveniências muito específicas, impondo-se aos sujeitos, estes estão na presença de uma moral da coerção, sem conteúdo ético, precisamente porque os interesses particulares ou os que se explicitam como se fossem coletivos não podem ter a pretensão à universalidade.

Como os sujeitos que pertencem a grupos ou organizações sabem que seus interesses pessoais não podem ser expressos como sendo pessoais, vão buscar um discurso cobertura que transforme esse interesse parti- 
cular em uma razão coletiva aceita, capaz de conferir legitimidade ao que não é necessariamente legítimo. É por essa razão que a cena política e social precisa valorizar, como sugere Marilena Chauí, um outro tipo de sujeito, o coletivo - que vincula ética e moral, ética e direito, ética e cidadania, ética e democracia -, de maneira que a distinção entre a esfera privada da ética e a esfera pública da moral não possa mais ser mantida, pois não há ética sem garantia de direitos: "a questão ética tornou-se inseparável da democrática, na medida em que a democracia afirma os princípios da igualdade, da justiça, da liberdade e da felicidade como direitos universais, criados pelos agentes sociais, assim como o princípio do direito às diferenças, universalmente reconhecidas como legítimas por todos".

Tratando da ética, Humberg afirma, logo no início de seu livro, que a honestidade é uma qualidade difícil de se encontrar entre os políticos. Após discorrer sobre as qualidades de um bom presidente, o autor declara sua preferência. Seria ético o julgamento por ouvir dizer? Seria ético o conceito preconcebido? Seria a ética mero bom senso? Humberg não faz bom uso do que aconselha. Ao propor uma mudança ética para o Brasil, sugere que a mesma seja liderada por empresários: com que ética? Com a ética dos negócios? Por que os empresários seriam possuidores de uma ética nacional/universal? O próprio Humberg reconhece que a ética das "grandes empreiteiras" não é digna de exemplo.

Depois de investir no tema, o autor define o objeto de seu texto e, com isso, deixa clara a razão de algumas de suas dificuldades analíticas. "Ética organizacional é um comportamento regido por padrões cla- ros, explícitos, que correspondem à postura real dos dirigentes dessa organização". A ética é parte da cultura e não corresponde a valores morais ou religiosos "embora seja de se esperar que isto ocorra". Uma postura pode ser real sem ser necessariamente ética. Valores religiosos podem corresponder a uma certa moral mas não à toda moral. Assim, Humberg também deixa claro o foco de suas considerações: a relação empresa-governo-política e seus correlatos.

De fato, ética e moral vinculam-se à prática política, constituindo-se em meios de julgamento. Quando atitudes políticas são tomadas, é inevitável que sejam apreciadas pelos diretamente atingidos e, muitas vezes, até mesmo pelos que por elas não são afetados. A avaliação das atitudes acaba por se referir, grosso modo, às noções de certo e de errado, bom ou mau, seja do ponto de vista dos códigos individuais - da ética -, seja das normas sociais - da moral. Como ensina Heemann, esses padrões aglutinam-se em três grandes grupos: a. o teleológico, em que o padrão para a decisão moral depende de suas conseqüências;

b. o deontológico, em que o padrão para a decisão moral pode ser obrigatória ou correta pelo bem que promove ou, igualmente, por sua natureza; e

c. o relativista, que recusa os princípios absolutos oriundos do fim último ou do dever, admitindo-os em um quadro espaço-tempo mutável.

É ainda Heemann quem destaca que os juízos morais particulares gerais - juízo de obrigação e de valor, por exemplo - podem representar um núcleo do comportamento moral. Já Ricoeur propõe uma distinção entre ética e moral que, embora convencional, é de muita utilidade para anali- sar as considerações de Humberg: o termo "ética" é reservado à "perspectiva de uma vida concluída" e o termo "moral", à "articulação dessa perspectiva em normas caracterizadas ao mesmo tempo pela pretensão à universalidade e por um efeito de constrangimento". Isso implica que "a moral somente constituiria uma efetuação limitada, embora legítima e mesmo indispensável, da perspectiva ética, e a ética nesse sentido envolveria a moral", de forma que a perspectiva ética - o momento teleológico - corresponde à estima de si, e a moral - o momento deontológico -, o respeito de si. Nesse sentido, deve ser "evidente: 1) que a estima de si é mais fundamental que o respeito de si; 2) que o respeito de si é o aspecto que reveste a estima de si sob o regime da norma; 3) enfim, que as aporias do dever criam situações em que a estima de si aparece não somente como a origem mas como o recurso do respeito quando já nenhuma norma certa oferece guia seguro para o exercício hic et nunc do respeito". Em síntese, Ricoeur conclui que "a distinção entre ética e moral responde à obrigação humana de um fosso lógico entre prescrever e descrever, entre dever-ser e ser", de forma que, se o ponto de vista deontológico subordina-se à perspectiva teleológica, então "a distância entre dever-ser e ser parecerá menos intransponível que em uma confrontação direta entre a descrição e a prescrição ou, segundo uma terminologia próxima, entre julgamentos de valor e julgamentos de fato".

O que se depreende dessa análise kantiana é que o sujeito, embora possa ser constrangido pelas regras da moral, é capaz de definir, em circunstâncias específicas em que o respeito de si pelo outro passa a ser um código valorizado pelo sentimento de pertença a seu próprio grupo ou pela 
ocupação de espaços políticos de poder nas organizações, uma perspectiva teleológica ditada por outra razão. Assim, como a estima de si - a ética - é mais fundamental que o respeito de si - a moral -, o sujeito pode propor justificações a si, de tal forma que a moral, já não tendo a última palavra, pode conviver, nas organizações, com outras éticas que não lhe correspondem, e os sujeitos nem por isso irão se sentir totalmente desconfortáveis por essa distinção. Humberg não percebe essa questão e por isso pode propor uma ética empresarial como solução.

O que justifica a prática de uma ética em desacordo com os códigos morais pode ser ou a falta de condição da norma para continuar a oferecer um "guia seguro" ou as aprecia- ções de caráter avaliativo, tanto da ética como da moral. Neste segundo caso, a prática é aquela em que a qualificação da ética passa a ser assegurada não por sua correspondência ou pela necessidade de renovação deontológica, mas pelo desenvolvimento de "padrões de excelência", como afirma Macintyre, os quais definem o sucesso esperado, tornando-se regras aceitas por uma certa coletividade organizacional e interiorizada por seus membros. Tal prática resulta em atividades com regras "socialmente estabelecidas", cujos padrões têm "sua própria história" para justificar os critérios do que é uma organização bem-sucedida e do que são seus melhores "colaboradores". Na prática organizacional, esses padrões - nem sempre escritos, mas usualmente sugeridos nas definições das estratégias - levam os sujeitos a conviverem com conjuntos de diferentes códigos - os do dever-ser e os do ser -, o que os leva a valorizar mais o parecer-ser do que o de-fato-ser.

A falta de uma definição mais profunda de ética, leva Humberg a tratar do tema de forma excessivamente genérica e pouco precisa. Entretanto, não posso, ao final, deixar de reconhecer que Humberg tem uma preocupação original e que, independentemente da profundidade, trata de um tema que possui muitos adeptos no plano do discurso e poucos no plano das atitudes. Dessa forma, sinto-me à vontade para criticar suas análises e para elogiar suas intenções. 